Results: The population ranged from 35- 90 years and duration of RA from 1- 30 years. CCP Ab was present in $75 \%$ of patients and RF in $71 \%$. Patients were on DMARDs either monontherapy (29\%), dual therapy $(60 \%)$ or triple therapy $(10 \%)$. Antirheumatic medications used were plaquenil, methotrexate, leflunomide, etanercept, adalimumab, infliximab, tofacitinib, upadacitinib and rituximab. ESR range was 2-110 and CRP 0.283.1. The CDAI and RAPID3 concordance was found to be $37 \%$ with RAPID3 being higher in $45 \%$ of patients. RAPID3 was lower only in $14 \%$ of patients. There was incorrect calculation of the RAPID3 $26 \%$ of the time by clinic staff. Table 1 summarizes this data. Figure 1 shows RAPID3 and CDAl compared in scatterplots.

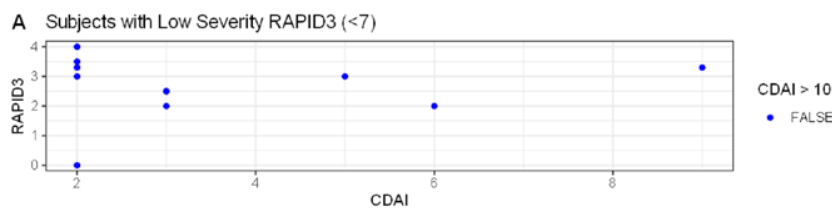

B Subjects with Moderate Severity RAPID3 (7-13)

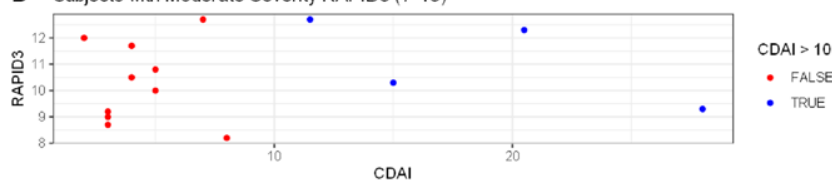

C Subjects with High Severity RAPID3 (>13)

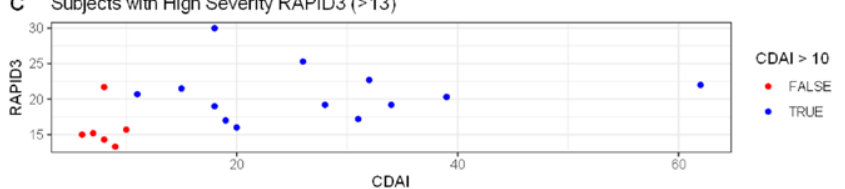

D Subjects with High Severity RAPID3 ( $>13)$

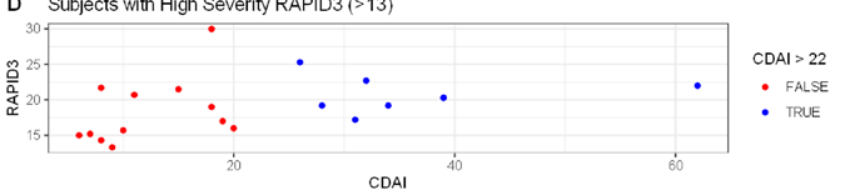

Figure 1. Scatterplots of three RAPID3 strata. Red dots represent discordant subjects when compared to CDAl.Note: Panel $\mathrm{C}$ demonstrates the subjects that were in low disease activity in red that had a high severity RAPID3 score

Conclusion: This study shows that RAPID3 may overestimate disease activity level for patients above low disease activity. Treatment escalation based on RAPID3 in discordant patients may be inappropriate. When making treatment decisions, a measure that includes objective physical examination and provider judgment is desirable.

REFERENCES:

[1] Kumar, B. S., Suneetha, P., Mohan, A., Kumar, D. P. \& Sarma, K. V. S. Comparison of Disease Activity Score in 28 joints with ESR (DAS28), Clinical Disease Activity Index (CDAI), Health Assessment Questionnaire Disability Index (HAQ-DI) \& Routine Assessment of Patient Index Data with 3 measures (RAPID3) for assessing disease activity in patients with rheumatoid arthritis at initial presentation. Indian J Med Res 146, S57-S62 (2017)

[2] Pincus, T., Swearingen, C. J., Bergman, M. \& Yazici, Y. RAPID3 (Routine Assessment of Patient Index Data 3), a Rheumatoid Arthritis Index Without Formal Joint Counts for Routine Care: Proposed Severity Categories Compared to Disease Activity Score and Clinical Disease Activity Index Categories. The Journal of Rheumatology 35, 2136-2147 (2008).

Disclosure of Interests: None declared

DOI: 10.1136/annrheumdis-2021-eular.1682

\section{AB0120 IDENTIFYING CORE VARIABLES TO DEVELOP A SEVERITY INDEX IN RHEUMATOID ARTHRITIS: A NATIONWIDE DELPHI CONSENSUS}

S. C. Rodriguez-García ${ }^{1}$, E. Toledano Martinez² ${ }^{2}$ M. J. García de Yébenes ${ }^{3}$, L. Carmona ${ }^{3}$, I. González-Álvaro ${ }^{1}{ }^{1}$ Hospital de La Princesa, Rheumatology, Madrid, Spain; ${ }^{2}$ Hospital Clinico Universitario San Carlos, Rheumatology, Madrid, Spain; ${ }^{3}$ Instituto de Salud Musculoesquelética (InMusc), Research Unit, Madrid, Spain

Background: Early interventions during the "window of opportunity" have been shown to improve clinical outcomes in rheumatoid arthritis (RA). However, intensive treatment can induce toxicity so identifying patients most likely to benefit from it is of great importance. Hence, tools for guiding therapeutic decisions in early disease stages are needed.
Objectives: To identify core variables to develop a RA severity index according to an expert panel.

Methods: An expert panel was prompted to analyze relevant variables to define a "severity" construct, specified as "early severe disease", able to classify patients with data collected on the first 2 years of the disease. They were also asked to identify potential modifying factors and external criteria to evaluate criterion validity.

An anonymous nationwide 2-round Delphi survey was applied to look for consensus about: (1) the priority of inclusion of each variable, (2) the feasibility to obtain them from usual sources (e.g., medical records) and (3) their definition. Each item was rated on a 10-point (priority) or 5-point (feasibility and definition) Likert scales were $0=$ complete disagreement and 5-10=complete agreement.

After the $1^{\text {st }}$ round, any item rated from 5 to 10 in priority and 3 to 5 for feasibility by at least $70 \%$ of responders was included in the final variable list. Items no reaching at least $20 \%$ consensus were discarded. The remaining ones would be voted again in the $2^{\text {nd }}$ round and adopted if they reached at least $50 \%$ consensus or else discarded.

Results: The task force identified 17 variables to define the "severity" construct (Table 1). Socio-economic status, knowledge of their own disease, type or work adherence to treatment, among others were proposed modifying factors. Rheumatoid factor or anti-citrullinated peptide antibody seropositivity as predictive factors The physician global assessment and the "burden of treatment" (lines of treatment, number and dose of DMARDs and cumulative steroid dose received were proposed for evaluating criterion validity.

A total of 61 stakeholders from across Spain took the survey, $56 \%$ were female and had 19.8 years of average experience after training. All variables were included after $1^{\text {st }}$ round. Nonetheless, definitions were submitted for a $2^{\text {nd }}$ round after rephrasing, including comments received on the survey. The final list was reduced to 15 items after merging 3 of the initial variables into a new one called "refractoriness"(Table 1).

Conclusion: The consensus process resulted in a list of variables and modifying factors deemed of relevance for the severity construct as we defined it. These items will be used to develop a severity index to guide treatment decisions in early disease stages.

Table 1. Variables proposed for the severity construct.

\begin{tabular}{|c|c|c|c|}
\hline $\mathrm{N}$ & $\begin{array}{l}\text { Initially proposed } \\
\text { variables }\end{array}$ & $\mathrm{N}$ & $\begin{array}{c}\text { Final variables after } \\
\text { Delphi }\end{array}$ \\
\hline 1 & Polyarthritis & 1 & Polyarthritis \\
\hline 2 & Big joint involvement & 2 & Big joint involvement \\
\hline 3 & $\begin{array}{l}\text { High disease activity at } 2 \text { years of } \\
\text { follow-up }\end{array}$ & 3 & $\begin{array}{c}\text { High disease activity at } 2 \\
\text { years of follow-up }\end{array}$ \\
\hline 4 & $\begin{array}{l}\text { Maintained disease activity in the first } \\
\qquad 2 \text { years }\end{array}$ & 4 & $\begin{array}{l}\text { Maintained disease activ- } \\
\text { ity in the first } 2 \text { years }\end{array}$ \\
\hline 5 & $\begin{array}{c}\text { Acute phase reactants persistently } \\
\text { elevated }\end{array}$ & 5 & $\begin{array}{l}\text { Acute phase reactants } \\
\text { persistently elevated }\end{array}$ \\
\hline 6 & Extra-articular manifestations & 6 & $\begin{array}{l}\text { Extra-articular } \\
\text { manifestations }\end{array}$ \\
\hline 7 & Failure to reach remission & 7 & Failure to reach remission \\
\hline 8 & $\begin{array}{l}\text { Need for aggressive therapy in the } \\
\text { first } 2 \text { years }\end{array}$ & 8 & $\begin{array}{c}\text { Need for aggressive } \\
\text { therapy in the first } 2 \\
\text { years }\end{array}$ \\
\hline 9 & Presence of erosions at diagnosis & 9 & $\begin{array}{c}\text { Presence of erosions by } \\
\text { at diagnosis }\end{array}$ \\
\hline 10 & $\begin{array}{c}\text { Number of erosions at } 2 \text { years of } \\
\text { follow-up }\end{array}$ & 10 & $\begin{array}{c}\text { Number of erosions at } 2 \\
\text { years of follow-up }\end{array}$ \\
\hline 11 & Lack of improvement in the HAQ-DI & 11 & $\begin{array}{c}\text { Lack of improvement in } \\
\text { the HAQ-DI }\end{array}$ \\
\hline 12 & Need for prosthetic surgery & 12 & $\begin{array}{c}\text { Need for prosthetic } \\
\text { surgery }\end{array}$ \\
\hline 13 & Hospital Admissions & 13 & Hospital Admissions \\
\hline 14 & Cortico-dependence & 14 & Cortico-dependence \\
\hline 15 & $\begin{array}{c}\text { MTX withdrawal due to loss of } \\
\text { efficacy }\end{array}$ & 15 & Refractoriness \\
\hline 16 & Completely absent response to MTX & & \\
\hline 17 & Number of drugs with lack of efficacy & & \\
\hline
\end{tabular}

Underlined variables on the left were merged into a new variable called "Refractoriness" HAQ-DI: Health Assessment Questionnaire-Disability Index

Disclosure of Interests: Sebastián C Rodriguez-García Speakers bureau: Roche, Sanofi, MSD, UCB-Pharma, Bristol-Myers-Squibb, Novartis, janssen, Consultant of: Bristol-Myers-Squibb, Galapagos, ESTHER TOLEDANO MAR TINEZ: None declared, María Jesús García de Yébenes: None declared, Loreto Carmona Grant/research support from: Novartis Farmacéutica, SA, Pfizer S.L.U., Merck Sharp \& Dohme España, S.A., Roche Farma, S.A, Sanofi Aventis, AbbVie Spain, S.L.U., and Laboratorios Gebro Pharma, SA, Isidoro González-Álvaro Speakers bureau: Abbvie, MSD, Roche, Lilly, Paid instructor for: Lilly, Consultant of: Lilly, Sanofi, Grant/research support from: Roche DOI: 10.1136/annrheumdis-2021-eular.182 